\title{
Increased gastric production of interleukin-8 and tumour necrosis factor in patients with Helicobacter pylori infection
}

\author{
X-G Fan, A Chua, X-J Fan, P W N Keeling
}

\begin{abstract}
Aims-To investigate the role of interleukin-8 (IL-8) and tumour necrosis factor (TNF) in patients infected with Helicobacter pylori.

Methods-The study population comprised 52 patients with dyspepsia attending for upper gastrointestinal endoscopy. Of these patients, 35 were infected with $H$ pylori. IL-8 and TNF concentrations in plasma, gastric juice, and gastric biopsy homogenate supernatant fluid were measured by radioimmunoassay and $L 929$ cell bioassay, respectively.

Results-The concentrations of IL-8 and TNF in gastric juice and gastric biopsy homogenates were substantially greater in patients infected with $H$ pylori. In $H$ pylori positive patients IL-8 concentrations in gastric juice and gastric biopsy homogenates were higher in those with moderate gastritis than in those with mild gastritis. There was a positive correlation between IL-8 and TNF concentrations in gastric juice and gastric biopsy homogenate supernatant fluid from $H$ pylori positive patients. There were no significant differences between $H$ pylori positive and negative patients with respect to IL-8 and TNF plasma concentrations.

Conclusion-This study suggests that increased gastric production of IL-8 and TNF may be implicated in the pathogenesis of $H$ pylori associated gastroduodenal disease.

(f Clin Pathol 1995;48:133-136)
\end{abstract}

Keywords: Interleukin-8, tumour necrosis factor, Helicobacter pylori.

Helicobacter pylori infection has been implicated in the pathogenesis of active chronic gastritis and peptic ulcer disease. Neutrophil accumulation in gastric tissue is one of the characteristics of this condition. ${ }^{2}$ Inflammatory mediators, such as interferon- $\gamma$, have been closely correlated with $H$ pylori associated gastritis and duodenal ulcer. ${ }^{34}$ Little is known, however, about the potential importance of interleukin-8 (IL-8), a novel cytokine which activates neutrophils, in patients infected with H pylori.

Interleukin-8 is a potential mediator of the inflammatory response. In addition to chemotactic potential, IL-8 is capable of activating polymorphonuclear leucocyte de- granulation, the respiratory burst, and the 5lipoxygenase pathway. ${ }^{56}$ Interleukin-8 is generated by a variety of immune and non-immune cells, including macrophages/monocytes, endothelial cells, fibroblasts, hepatocytes, and polymorphonuclear leucocytes ${ }^{57-9}$; IL-8 may also be a component of the inflammatory cascade. Tumour necrosis factor (TNF) has many important biological functions and is produced mainly by activated macrophages/monocytes and $T$ lymphocytes. ${ }^{10}$ In addition to its oncolytic activity, it may be a primary mediator in the pathogenesis of infection, injury, and inflammation. ${ }^{112}$ As such, TNF may exert an effect on IL-8, a hypothesis tested in this study.

\section{Methods}

Prepyloric antral biopsy specimens were obtained from 52 patients with dyspepsia attending for upper gastrointestinal endoscopy. None of the patients studied were taking nonsteroidal anti-inflammatory drugs, bismuth compounds, or antibiotics. Patients with evidence of malignant disease and those undergoing immunosuppressive treatment were excluded. $H$ pylori infection was assessed histologically by Giemsa stain and the rapid urease test (CLO-test, Delta West Ltd., Bentley, Australia). Of the 52 patients, 35 (19 men and 16 women; mean age $45 \cdot 6$ years, range $20-73$ years) were infected with $H$ pylori, 14 of whom had duodenal ulcer, while a further 21 had gastritis. The remaining 17 patients (seven men and 10 women; mean age $44 \cdot 1$ years, range 22-77 years) were $H$ pylori negative with normal results on gastrointestinal endoscopy and histology. These patients were diagnosed as having functional dyspepsia.

Plasma was isolated from venous blood with heparin as the anti-coagulant. Gastric juice was collected by aspiration of patients during endoscopy following a 12 hour fast, and was then centrifuged immediately at $3000 \mathrm{rpm}$ at $4^{\circ} \mathrm{C}$ for 30 minutes. Gastric biopsy specimens were immediately washed with phosphate buffered saline (PBS; $\mathrm{pH} 7 \cdot 4$ ), weighed, placed in a tube containing $0.5 \mathrm{ml} 0.01 \mathrm{M}$ PBS, and gently ground with a glass homogeniser for three minutes at $4^{\circ} \mathrm{C}$. Biopsy homogenates were then centrifuged at $3000 \mathrm{rpm}$ at $4^{\circ} \mathrm{C}$ for 30 minutes and the supernatant fluid removed. ${ }^{13}$ All samples were stored at $-70^{\circ} \mathrm{C}$ until analysed. Sample collection was not always successful and thus samples were not obtained from all patients or were sometimes too small to enable assay of both IL-8 and TNF. 
Interleukin-8 was measured by radioimmunoassay (Advanced Magnetics Inc., Cambridge, Massachusetts, USA). The assay was performed in duplicate according to the manufacturer's instructions. Tumour necrosis factor bioactivity was measured by bioassay of in vitro cytotoxicity against L929 cells. These assays have been evaluated previously. ${ }^{1415}$ Briefly, L929 cells were incubated for 24 hours at $37^{\circ} \mathrm{C}$ in 96 -well flat-bottomed microtitre plates at a concentration of $4 \times 10^{3}$ cells/well. Titrations of the TNF standard (Sigma, Lab Supplies Ltd., Dublin, Ireland) and dilutions of the samples in medium containing $2 \mu \mathrm{g} / \mathrm{ml}$

Table 1 Interleukin-8 concentrations in $H$ pylori positive and negative patients

\begin{tabular}{|c|c|c|c|}
\hline Patient status & $\begin{array}{l}\text { Plasma } \\
\text { (ng/ml) }\end{array}$ & $\begin{array}{l}\text { Gastric juice } \\
\text { (ng/ml) }\end{array}$ & $\begin{array}{l}\text { Gastric biopsy } \\
\text { homogenates } \\
\text { (ng/g wet weight) }\end{array}$ \\
\hline $\begin{array}{l}H \text { pylori positive } \\
\text { median } \\
\text { range } \\
\text { no. of patients }\end{array}$ & $\begin{array}{l}0 \cdot 090 \\
0 \cdot 002-0 \cdot 215 \\
34\end{array}$ & $\begin{array}{l}32 \cdot 60 \\
5 \cdot 04-39 \cdot 47 \\
31\end{array}$ & $\begin{array}{l}8 \cdot 86 \\
3 \cdot 90-20 \cdot 09 \\
35\end{array}$ \\
\hline $\begin{array}{l}H \text { pylori negative } \\
\text { median } \\
\text { range } \\
\text { no. of patients }\end{array}$ & $\begin{array}{l}0 \cdot 110 \\
0 \cdot 003-0 \cdot 186 \\
15\end{array}$ & $\begin{array}{l}21 \cdot 37 * * \\
0 \cdot 730-31 \cdot 35 \\
17\end{array}$ & $\begin{array}{l}6 \cdot 31^{*} \\
3 \cdot 16-14 \cdot 81 \\
17\end{array}$ \\
\hline
\end{tabular}

${ }^{*} \mathrm{p}<0.05,{ }^{* *} \mathrm{p}<0.01$ compared with $H$ pylori positive subjects.

Table 2 Interleukin-8 concentrations in $H$ pylori positive patients with gastritis

\begin{tabular}{|c|c|c|c|}
\hline Patient status & $\begin{array}{l}\text { Plasma } \\
(n g / m l)\end{array}$ & $\begin{array}{l}\text { Gastric juice } \\
(\mathrm{ng} / \mathrm{ml})\end{array}$ & $\begin{array}{l}\text { Gastric biopsy } \\
\text { homogenates } \\
\text { (ng/g wet weight) }\end{array}$ \\
\hline $\begin{array}{l}\text { Mild gastritis } \\
\text { median } \\
\text { range } \\
\text { no. of patients }\end{array}$ & $\begin{array}{l}0 \cdot 10 \\
0 \cdot 002-0 \cdot 215 \\
10\end{array}$ & $\begin{array}{l}20 \cdot 25 \\
6 \cdot 50-36 \cdot 39 \\
10\end{array}$ & $\begin{array}{l}8 \cdot 50 \\
3 \cdot 90-12 \cdot 24 \\
10\end{array}$ \\
\hline $\begin{array}{l}\text { Moderate gastritis } \\
\text { median } \\
\text { range } \\
\text { no. of patients }\end{array}$ & $\begin{array}{l}0 \cdot 103 \\
0 \cdot 003-0 \cdot 194 \\
11\end{array}$ & $\begin{array}{l}33 \cdot 50^{*} \\
5 \cdot 04-39 \cdot 47 \\
10\end{array}$ & $\begin{array}{l}11 \cdot 38^{*} \\
5 \cdot 31-20 \cdot 09 \\
11\end{array}$ \\
\hline
\end{tabular}

${ }^{*} \mathrm{p}<0.05$ compared with patients with mild gastritis.

Table 3 Interleukin-8 concentrations in $H$ pylori positive patients with duodenal ulcer or gastritis alone

\begin{tabular}{|c|c|c|c|}
\hline Patient status & $\begin{array}{l}\text { Plasma } \\
\text { (ng/ml) }\end{array}$ & $\begin{array}{l}\text { Gastric juice } \\
(n g / m l)\end{array}$ & $\begin{array}{l}\text { Gastric biopsy } \\
\text { homogenates } \\
\text { (ng/g wet weight) }\end{array}$ \\
\hline $\begin{array}{l}\text { Duodenal ulcer } \\
\text { median } \\
\text { range } \\
\text { no. of patients }\end{array}$ & $\begin{array}{l}0.092 \\
0.008-0 \cdot 143 \\
13\end{array}$ & $\begin{array}{l}35 \cdot 0 \\
11 \cdot 22-37 \cdot 12 \\
11\end{array}$ & $\begin{array}{l}9 \cdot 0 \\
4 \cdot 92-12 \cdot 11 \\
14\end{array}$ \\
\hline $\begin{array}{l}\text { Gastritis } \\
\text { median } \\
\text { range } \\
\text { no. of patients }\end{array}$ & $\begin{array}{l}0 \cdot 103 \\
0 \cdot 002-0 \cdot 215 \\
21\end{array}$ & $\begin{array}{l}31 \cdot 0 \\
5 \cdot 04-39 \cdot 4 \\
20\end{array}$ & $\begin{array}{l}10 \cdot 25 \\
3 \cdot 90-20 \cdot 09 \\
21\end{array}$ \\
\hline
\end{tabular}

Table 4 Tumour necrosis factor concentrations in $H$ pylori positive and negative patients

\begin{tabular}{|c|c|c|c|}
\hline Patient status & $\begin{array}{l}\text { Plasma } \\
\text { (ng/ml) }\end{array}$ & $\begin{array}{l}\text { Gastric juice } \\
\text { (ng/ml) }\end{array}$ & $\begin{array}{l}\text { Gastric biopsy } \\
\text { homogenates } \\
\text { (ng/g wet weight) }\end{array}$ \\
\hline $\begin{array}{l}H \text { pylori negative } \\
\text { median } \\
\text { range } \\
\text { no. of patients }\end{array}$ & $\begin{array}{l}19 \cdot 0 \\
10 \cdot 60-50 \cdot 48 \\
12\end{array}$ & $\begin{array}{l}213.75 \\
100 \cdot 51-417.89 \\
12\end{array}$ & $\begin{array}{l}101 \cdot 0 \\
41 \cdot 56-127 \cdot 62 \\
12\end{array}$ \\
\hline $\begin{array}{l}H \text { pylori positive } \\
\text { median } \\
\text { range } \\
\text { no. of patients }\end{array}$ & $\begin{array}{l}22 \cdot 12 \\
11 \cdot 86-63 \cdot 46 \\
27\end{array}$ & $\begin{array}{l}313 \cdot 75^{*} \\
104.89-542 \cdot 61 \\
27\end{array}$ & $\begin{array}{l}173 \cdot 33 * * \\
69 \cdot 90-311 \cdot 24 \\
27\end{array}$ \\
\hline
\end{tabular}

${ }^{*} \mathrm{p}<0.05,{ }^{* *} \mathrm{p}<0.001$ compared with $H$ pylori negative patients. actinomycin D (Sigma) were added to the wells and incubated for 24 hours at $37^{\circ} \mathrm{C}$. Then $20 \mu \mathrm{l}$ of 3-(4,5-dimethylthiazol-2-yl)-2,5-diphenyl tetrazolium bromide (MTT; Sigma), at a concentration of $6 \mathrm{mg} / \mathrm{ml}$, were added to the wells and the plates incubated for four hours at $37^{\circ} \mathrm{C}$. MTT was then removed and $200 \mu$ of dimethyl sulphoxide (DMSO) added to each well. Absorbance was read at $570 \mathrm{~nm}^{16}$

Data are expressed as median (range) and were analysed using the Mann-Whitney $U$ test for non-parametric data and linear regression analysis.

\section{Results}

Interleukin-8 concentrations in gastric juice and biopsy homogenate supernatant fluid were increased in patients with $H$ pylori infection compared with those without $H$ pylori infection, but this difference was not observed for plasma IL-8 concentrations (table 1). Interleukin-8 concentrations in gastric juice and biopsy homogenate supernatant fluid were increased in patients with moderate compared with those with mild gastritis; there was no difference in plasma IL-8 concentrations between these two groups (table 2). Furthermore, IL-8 concentrations in plasma, gastric juice and biopsy

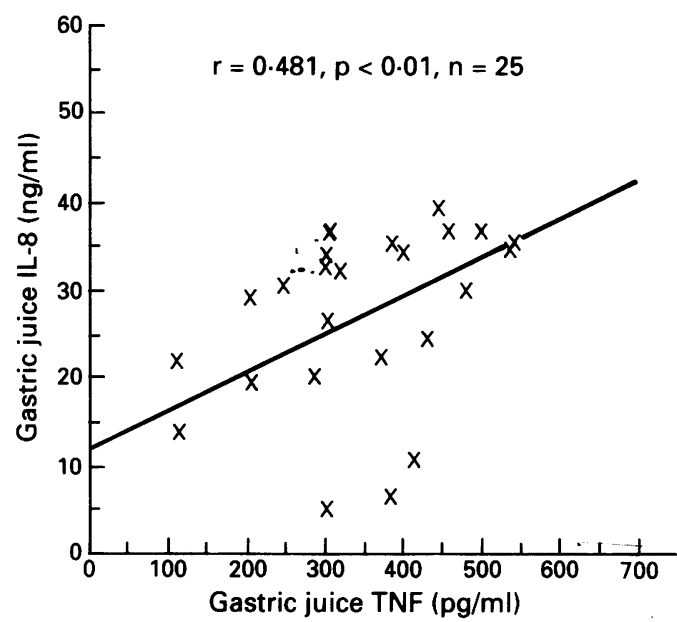

Figure 1 Correlation between $I L-8$ and TNF concentrations in gastric juice of $H$ pylori positive patients.

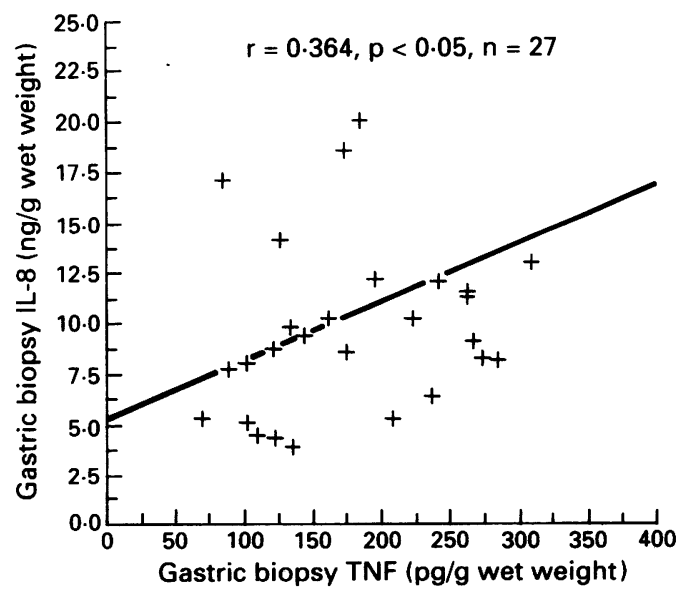

Figure 2 Correlation between $I L-8$ and TNF concentrations in gastric biopsy homogenate supernatant fluid of $H$ pylori positive patients. 
homogenate supernatant fluid were not significantly different in patients with duodenal ulcer when compared with those with gastritis alone (table 3).

Tumour necrosis factor concentrations in gastric juice and biopsy homogenate supernatant fluid were significantly higher in $H$ pylori positive patients (table 4), but were not significantly different $(p>0.05)$ when patients with gastritis were compared with those with duodenal ulcer or when patients with moderate gastritis were compared with those with mild gastritis (data not shown).

There was a positive correlation between IL8 and TNF concentrations in gastric juice (fig 1) and in gastric biopsy homogenate supernatant fluid (fig 2) of $H$ pylori positive patients.

To investigate whether TNF from gastric juice is affected by $\mathrm{pH}$, the following experiment was performed: dilutions $(50 \mathrm{pg} / \mathrm{ml})$ of TNF standard were added to six tubes and $\mathrm{pH}$ values were adjusted to $3,7 \cdot 4$, and $8 \cdot 5$, in duplicate, using $\mathrm{HCl}$ or $\mathrm{NaOH}$, respectively. The concentration of TNF in each of these tubes was measured. The results $(48 \cdot 22,50 \cdot 54$, and $48.70 \mathrm{pg} / \mathrm{ml}$ TNF, respectively) indicated that $\mathrm{pH}$ has no apparent influence on TNF activity. As the IL-8 radioimmunoassay kit is expensive, we did not investigate the effect of $\mathrm{pH}$ on IL- 8 concentrations.

\section{Discussion}

This study demonstrates that IL- 8 and TNF are present at high concentrations in gastric juice and biopsy homogenate supernatant fluid of patients infected with $H$ pylori. Interleukin8 concentrations were related to the severity of gastritis. Our findings suggest that increased local production of IL-8 and TNF may play an important role in the induction of the gastric mucosal damage associated with $H$ pylori infection. Although IL-8 and TNF concentrations were elevated in the gastric juice and biopsy homogenate supernatant fluid of $H$ pylori positive patients, concentrations of circulating IL-8 and TNF were unchanged. This dichotomy between local and systemic IL-8 and TNF responses indicates that the inflammatory response to $H$ pylori infection mainly occurs at the local level in gastric tissue and that local production of these cytokines may occur.

As reported previously, ${ }^{15}$ an inflammatory cell infiltrate, composed mainly of neutrophils, is present in $H$ pylori associated gastroduodenal disease. The continued accumulation of neutrophils at the site of inflammation could be an important pathogenic mechanism. ${ }^{17}$ The close histological association between $H$ pylori and the inflammatory infiltrate is indicative of recruitment by inflammatory mediators. Our study suggests that increased local IL-8 production may be responsible for attracting neutrophils to the site of inflammation ( $H$ pylori also secretes a chemotactic factor for phagocyte ${ }^{1819}$ ). Interleukin-8 is a potent and specific neutrophil chemotactic factor ${ }^{5}$ and may play an important role in the pathogenesis of the inflammatory response associated with $H$ pylori infection of the stomach and duodenum. Once the inflammatory cells are present, release of reactive oxygen radicals or proteolytic enzymes from stimulated neutrophils could induce tissue damage. ${ }^{20}$

Some studies have shown that TNF is an important mediator of inflammation and is closely related to the genesis of gastroduodenal inflammatory disease, ${ }^{34}$ an observation further supported by this study. Tumour necrosis factor can stimulate production of IL-8 in vivo or in vitro. ${ }^{52122}$ The observation, therefore, that increased local production of IL-8 was positively correlated with TNF activity in patients with $\mathrm{H}$ pylori infection is not unexpected. $\mathrm{Al}-$ though the cellular source of IL-8 in gastric juice and biopsy homogenate supernatant fluid is uncertain, we postulate that gastric epithelial cells, infiltrating inflammatory cells, including macrophages, neutrophils, and lymphocytes, have the potential to produce large amounts of IL-8..$^{52-24}$

In conclusion, our observations implicate inflammatory cytokines in the pathogenesis of $H$ pylori associated gastroduodenal diseases. The emerging understanding of the potential role of IL-8 and TNF in inflammation may provide a new basis for the design of antiinflammatory agents.

1 Blaser MJ. Hypothesis on the pathogenesis and natural history of Helicobacter pylori-induced inflammation. Gastroenterology 1992;102:720-7.

2 Wallace JL. Possible mechanisms and mediators of gastritis associated with Helicobacter pylori infection. Scand $\mathcal{f}$ Gastroenterol 1991;26(Suppl 187):65-70.

3 Mai UE, Perez-Perez GI, Wahl SM, Blaser MJ, Smith PD. Soluble surface proteins from Helicobacter pylori activate monocytes/macrophages by a lipopolysaccharide-independent mechanism. $f$ Clin Invest 1991;87:894-900

4 Fan XJ, Chua A, O'Connell M, Kelleher D, Keeling PWN. Interferon-gamma and tumour necrosis factor production in patients with Helicobacter pylori infection. Ir $\mathcal{f} \mathrm{Med}$ Sci 1993;162:408-11.

5 Baggiolini M, Walz A, Kunkel L. Neutrophil-activating peptide-1/interleukin 8, a novel cytokine that activates neutrophils. $\mathcal{F}$ Clin Invest 1989;84:1045-9.

6 Willems J, Joniau S, Cinque S, Van Damme J. Human granulocyte chemotactic peptide (IL-8) as a specific neutrophil degranulator: comparison with other monokines. trophil degranulator: comparis

7 Peveri P, Walz A, Dewald B, Baggiolini M. A neutrophilactivating factor produced by human mononuclear phagocytes. F Exp Med 1988;167:1547-59.

8 Strieter RM, Kunkel HJ, Showell HJ. Endothelial cell gene expression of a neutrophil chemotactic factor by TNF, IL1 $\beta$ or LPS. Science 1989;243:1467-9.

9 Schroder JM, Christophers E. Secretion of novel and homologous neutrophil-activating peptides by LPS-stimulated human endothelial cells. F Immunol 1989;142. 244-51.

10 Le J, Vilcek J. Tumor necrosis factor and interleukin 1 : cytokines with multiple overlapping biological activities. cytokines with multiple overt
Lab Invest 1987;56:234-8.

11 Beutler B, Cerami A. Cachectin and tumour necrosis factor as two sides of the same biological coin. Nature 1986;320: as two sides.

12 Beutler B, Milsark IW, Cerami A. Passive immunization against cachectin/tumor necrosis factor protects mice from lethal effect of endotoxin. Science 1985;229:869-71.

13 Mitsuyama K, Sasaki E, Toyonaga A, Ikeda H, Tsuruta O, Irie $\mathrm{A}$, et al. Colonic mucosal interleukin-6 in inflammatory bowel disease. Digestion 1991;50:104-11.

14 Izzo RS, Witkon K, Chen AI, Hadjiyane C, Weinstein MI, Pellecchia C. Neutrophil-activating peptide (IL-8) in colonic mucosa from patients with Crohn's disease $S$ ) in colonic mucosa from patients with

15 Venn G, Nietfeld JJ, Duits AJ, Brennan FM, Arner E Covington $M$. Elevated synovial fluid levels of IL-6 and TNF associated with early experimental

16 Green LM, Reade JL, Ware CF. Rapid colorimetric assay for cell viability: application to the quantitation of cytotoxic and growth inhibitory lymphokines. F Immunol Methods 1984;70:257-68. 
17 Jones DM, Lessells AM, Eldridge J. Campylobacter-like organisms on the gastric mucosa: culture, histological and organisms on the gastric mucosa: culture, histolog
serological studies. $f$ Clin Pathol 1984;37:1002-6.

18 Andersen LP, Nielsen H. Chemotactic activity of Helicobacter pylori sonicate for human polymorphonuclear cobacter pylori sonicate for human polymorph

19 Craig PM, Territo MC, Karnes WE, Walsh JH. Helicobacte pylori secretes a chemotactic factor for monocytes an neutrophils. Gut 1992;33:1020-3.

20 Suzuki M, Miura S, Suematsu M, Fukumura D, Kurose I, Suzuki $\mathrm{H}$, et al. Helicobacter pylori-associated ammoni production enhances neutrophil-dependent gastric mucosal cell injury. Am f Physiol 1992;263:G719-25.

21 Sheron N, Williams R. IL-8 as a circulating cytokine: in- duction by recombinant tumor necrosis factor-alpha. Clin Exp Immunol 1992;89:100-3.

22 Van Deventer SJH, Hart $M$, van der Poll $T$, Hack CE Aarden LA. Endotoxin and tumor necrosis factor- $\alpha$-induced interleukin-8 release in humans. F Infect Dis 1993, 67:461-4.

23 Agace W, Hedges S, Andersson U, Andersson J, Ceska M Svanborg C. Selective cytokine production by epithelial cells following exposure to Escherichia coli. Infect Immun 1993;61:602-9.

24 Plusa S, Farmery S, Peichl P, Lindley IJD, Primrose JN, Crabtree JE. Secretion of immunologically and biologically active interleukin- 8 by a gastric epithelial cell line [abstract]. Gut 1993;34(Suppl 4):S15. 